Ks. Stanisław Dyk ${ }^{1}$

\title{
Aktualność homilii Orygenesa we współczesnym przepowiadaniu
}

Dzieła Ojców Kościoła są ważnym źródłem i inspiracją współczesnego przepowiadania. Dotyczy to zwłaszcza posoborowej homilii, która narodziła się między innymi z ruchu patrystycznego. Powrót przepowiadania do dzieł Ojców jest zawsze powrotem do świętych źródeł, a przez to okazją do głębszego poznania słowa Bożego i misterium Chrystusa, które ono objawia ${ }^{2}$. To przecież w tradycji patrystycznej w sposób szczególny kształtowało się rozumienie Pisma Świętego ${ }^{3}$, które jest jednym z głównych źródeł przepowiadania (por. KL 35, 2; 52). Ojcowie Kościoła jako bliżsi Jezusowi potrafili skupić się na istotnych prawdach wiary oraz wprowadzić w sens Kościoła i sakramentów ${ }^{4}$. W sposób głęboko

1 Ks. prof. dr hab. Stanisław Dyk, profesor zwyczajny i kierownik Katedry Homiletyki na Wydziale Teologii KUL; email: standyk@kul.pl; ORCID: 0000-0001-7337-0035.

2 Por. J. Twardy, Aktualizacja słowa Bożego w kaznodziejstwie, Przemyśl 2009, s. 209.

3 Papieska Komisja Biblijna, Interpretacja Biblii w Kościele, w: Interpretacja Biblii w Kościele. Dokument Papieskiej Komisji Biblijnej z komentarzem biblistów polskich, red. R. Rubinkiewicz, Warszawa 1999, s. 74 (III B, 2): „Ojcowie Kościoła, którzy odegrali szczególną rolę w procesie kształtowania się kanonu mają podobną rolę założycieli w stosunku do żywej tradycji, która nieustannie towarzyszy i kieruje lekturą i interpretacją, którą podejmuje Kościół odnośnie do Pism [...]. W nurcie wielkiej Tradycji szczególny wkład egzegezy patrystycznej polega na tym: wydobyła ona z całości Pisma podstawowe orientacje, które nadały kształt tradycji doktrynalnej Kościoła, i dostarczyła bogatej wiedzy teologicznej do nauki i duchowego pokarmu dla wiernych".

4 Por. M. Szram, Homilia i kazanie patrystyczne jako wzorzec dla współczesnych kaznodziejów, w: Integralne kształcenie kaznodziei, red. W. Broński, Lublin 2006, s. 165. 
teologiczny, a zarazem duchowy i egzystencjalny, wyjaśniają misteria chrześcijańskiej wiary objawione w Piśmie Świętym. Do korzystania z dorobku Ojców Kościoła zachęca współczesna refleksja homiletyczna ${ }^{5}$, a przede wszystkim dokumenty Kościoła ${ }^{6}$. Pośród tych ostatnich wyróżnić należy najnowszy dokument Kongregacji ds. Kultu Bożego i Dyscypliny Sakramentów pt. Dyrektorium Homiletyczne, który wiele razy wskazuje Ojców jako mistrzów egzegezy biblijnej i aktualizacji Słowa Bożego ${ }^{7}$. Sięganiu po dzieła Ojców sprzyja także obecny postęp w badaniach patrystycznych, między innymi krytyczne wydania pism Ojców Kościoła oraz nowe przekłady dzieł patrystycznych obecne na rynku wydawniczym.

W poniższym opracowaniu odwołamy się do twórczości Orygenesa (185-ok. 253), która zawsze posiadała szczególną wartość dla chrześcijańskiej homiletyki. Znaczenie Orygenesa dla myśli homiletycznej wiąże się zarówno z jego metodą wykładu tekstu biblijnego, jak też i z podejściem do samego przepowiadania, któremu nadaje właściwą mu wartość teologiczną. Po wielokroć w jego pismach odnaleźć można intuicję wskazującą na fakt, że głoszenie słowa Bożego wprowadza w relację z Chrystusem, daje dostęp do łaski zbawczej oraz buduje Kościół ${ }^{8}$. Między

5 Zob. np. K. Panuś, Przesłanie Ojców Kościoła dla współczesnego kaznodziejstwa, RBL 1 (2008) s. 127-135; L. Szewczyk, Ojcowie bardzo zalecani. Znaczenie kaznodziejstwa Ojców Kościoła dla wspótczesnego przepowiadania słowa Bożego, w: Omnia tempus habent. Miscellanea theologica Vincentio Myszor quadragesimum annum laboris scientifici celebranti ab amicis, sodalibus discipulisque oblata, red. A. Reginek G. Strzelczyk - A. Żądło, Katowice 2009, s. 283-291.

6 DK 19: „W czasie święceń biskup napomina prezbiterów, aby byli «dojrzali w wiedzy» i aby ich nauczanie było «duchowym lekarstwem dla ludu Bożego». Wiedza szafarza świętości powinna być święta, ponieważ została wzięta ze świętego źródła i do świętego celu jest skierowana. Przede wszystkim więc niech czerpie się ją z czytania i rozważania Pisma Świętego, ale także karmi się przez studium świętych ojców i doktorów Kościoła oraz innych dokumentów tradycji”.

7 Zob. Kongregacja Kultu Bożego i Dyscypliny Sakramentów, Dyrektorium Homiletyczne, Poznań 2015, nr 4, 17, 2; 25-27, 32, 88, 111.

8 Por. A. Olivar, La predicación cristiana antigua, Barcelona 1991, s. 62-69. Wystarczy tu choćby przytoczyć fragment homilii na Księgę Rodzaju, w której Orygenes podkreśla, że przepowiadanie to nie jedynie komentarz do Pisma, lecz czas budowa- 
innymi z powyższych racji Orygenes uznawany jest przez wielu za ojca chrześcijańskiej homilii. To właśnie jego przepowiadanie zaważyło na podejściu do homilii w dalszych dziejach Kościoła9. Stąd też w artykule ograniczymy się do refleksji nad homiliami Orygenesa. Jego homilie są wygłaszane w zgromadzeniu liturgicznym, przez co bardziej mogą posłużyć jako przykład dla dzisiejszej homilii. Ponadto, w porównaniu do komentarzy, homilie Orygenesa są krótsze, cechują się mniej wnikliwą egzegezą, a poziom wykładu Pisma Świętego dostosowany jest do percepcji słuchaczy, wśród których znaleźć można zarówno katechumenów, jak też i osoby ochrzczone, czy to niedawno nawrócone, czy też urodzone w rodzinach chrześcijańskich, ludzi z rozmaitych warstw społecznych i znajdujących się na różnym poziomie życia duchowego ${ }^{10}$.

Celem artykułu będzie wskazanie, na ile homilie Orygenesa moga być przykładem i inspiracją dla współczesnego przepowiadania homilijnego. Abstrahować tu będziemy od samej teologii Orygenesa, w tym od wpływów filozofii platońskiej na jego myśl. Nie będziemy także kreślić wielkich tematów teologicznych obecnych w jego homiliach. Odniesiemy się tu głównie do formalnych aspektów przepowiadania Orygenesa. Wskażemy przy tym na dwa elementy Orygenesowej metody homiletycznej, a mianowicie na duchową interpretację Pisma Świętego oraz na metodę komunikacji orędzia zbawczego. Na poszczególnych etapach

nia Kościoła i pobożności: „nie czas teraz na komentarze, pora na budowanie Kościoła Bożego i na pobudzanie leniwych i gnuśnych słuchaczy za pomocą przykładów oraz za pomocą mistycznych objaśnień" (Origenes, In Genesim hom. 10, 5, ed. H. de Lubac L. Doutreleau, SCh 7bis, Paris 1985, s. 318-320, t1. S. Kalinkowski: Orygenes, Homilie o Księdze Rodzaju, w: Orygenes, Homilie o Księdze Rodzaju. Homilie o Księdze Wyjścia, ŹMT 64, Kraków 2012, s. 118).

9 Por. E. Staniek, Koncepcja homilii patrystycznej, VoxP 44-45 (2003) s. 30.

10 H. Pietras, Wprowadzenie, w: Orygenes, Homilie o Księdze Rodzaju. Homilie o Księdze Wyjścia, tł. S. Kalinkowski, ŹMT 64, Kraków 2012, s. 10-12; A. Monaci Castagno, Origene, w: Dizionario di Omiletica, red. M. Sodi-A.M. Triacca, Torino-Bergamo 1998, s. 1051; E. Staniek, Koncepcja homilii patrystycznej, s. 30. Zob. E. Stanula, Homiletyczna działalność Orygenesa, w: Orygenes, Homilie o Księdze Jeremiasza, Homilie o Księgach Samuela i Księgach Królewskich, tł. S. Kalinkowski, PSP 30, Warszawa 1983, s. 5-20; A. Monaci Castagno, Origene predicatore ed il suo pubblico, Milano 1987. 
refleksji metodę przepowiadania Orygenesa zestawimy z obecną myślą homiletyczną zawartą w dokumentach Kościoła i teologii. Jednocześnie damy odpowiedź na pytanie o aktualność homilii Orygenesa we współczesnym przepowiadaniu. Tym samym spróbujemy wskazać, w jaki sposób vox patrum może być słyszany na współczesnej ambonie. Powyższe cele dyktują charakter artykułu, który będzie nie tyle opracowaniem źródłowym, co przeglądowym i porównawczym.

\section{Orygenes jako mistrz duchowej interpretacji Pisma Świętego}

Orygenesa śmiało można uznać za największego egzegetę chrześcijańskiej starożytności ${ }^{11}$. Wypracował on własną metodę pracy nad tekstem biblijnym. Badacze wskazują na trzy podstawowe założenia egzegezy Orygenesa: każde słowo Pisma Świętego jest duchowo użyteczne dla czytelnika - por. 2Tm 3,16 (zasada praktyczna); utożsamienie wymowy duchowej tekstu z misterium Chrystusa prowadzące do wniosku, że studium Pisma ma sens jedynie wtedy, gdy pozwala dojść do Chrystusa (zasada chrystologiczna); oparcie egzegezy na dwupoziomowej, bytowej organizacji wszechświata, wedle której człowiek winien wznosić się nieustannie z poziomu niższego, zmysłowego na wyższy: duchowy i inteligibilny (zasada strukturalna) ${ }^{12}$.

Orygenes interpretuje Pismo Święte w oparciu o trychotomiczną budowę człowieka opisaną przez św. Pawła jako ciało, dusza i duch (1Tes 5,23). W tym sensie „ciału” odpowiada sens literalny, „duszy” sens moralny, a „duchowi” - sens duchowy Pisma Świętego ${ }^{13}$. Głównym

11 Por. H. Crouzel, Orygenes, Kraków 2004, s. 99-128.

12 Por. M. Simonetti, Między dosłownościa a alegorią. Przyczynek do historii egzegezy patrystycznej, Kraków 2000, s. 77-79; M. Składanowski, Myśl Orygenesa. Metodologiczne intuicje dla współczesnych teologów, „Studia Ełckie” 14 (2013) s. 158.

13 Por. H. Pietras, Wprowadzenie, w: Komentarz do Ewangelii wedtug św. Jana, tł. S. Kalinkowski, ŹMT, Kraków 2005, s. 7-9; A. Stanula, Teologiczne zasady interpretacji Pisma świętego, w: Orygenes, O zasadach, tł. S. Kalinkowski, PSP 23, Warszawa 1979, 
celem Orygenesa było, bez ignorowania sensu dosłownego ${ }^{14}$, dotarcie do najgłębszej warstwy znaczeniowej tekstu, do jego „ducha”, który pojmuje on jako „mądrość ukrytą”, „mądrość Bożą” (1Kor 2,7), jako „duchowe sprawy" dostępne tylko tym, którymi kieruje Duch Boży (por. 1Kor 2,1014). Tego rodzaju interpretacja jest także istotna $z$ powodu obecności w Biblii tekstów niejasnych, które są niemożliwe do właściwego odczytania na poziomie znaczenia literalnego. Tym samym Orygenes broni tekst natchniony przed lekturą fundamentalistyczną, która prowadzić może do interpretacji antropomorficznej, niemoralnej, niedorzecznej czy wręcz kompromitującej obraz Boga ${ }^{15}$.

Warto podkreślić, że sens duchowy Pisma był u Orygenesa ścisłe związany z misterium Chrystusa ${ }^{16}$. Wynikało to ze wspomnianej powyżej zasady chrystologicznej opartej na pojmowaniu Pisma Świętego jako Chrystusa - wcielonego Logosu. Całe Pismo Święte jako wcielone Słowo Boże ostatecznie ma zatem sens chrystologiczny. Zasada ta jest szcze-

s. 48-54. Swoje poglądy na temat sensów i interpretacji Pisma Świętego Orygenes przedstawił w swoim dziele $O$ zasadach: „Potrójnie więc należy zapisywać w swej duszy wszelkie rozumienie pism bożych: to znaczy, żeby każdy prosty człowiek czerpał zbudowanie z samego, że tak powiem, ciała Pisma - bo tak nazywamy pojmowanie zwyczajne i historyczne; jeśli zaś ktoś zaczął już czynić postępy i może patrzeć nieco szerzej, niech się buduje samą duszą Pisma; ci zaś, którzy są doskonali i podobni do tych, o których mówi Apostoł: «Głosimy mądrość między doskonałymi, ale nie mądrość tego świata ani mądrość władców tego świata, którzy giną, lecz głosimy mądrość Bożą ukrytą w tajemnicy, którą przed wiekami Bóg przeznaczył dla naszej chwały», niechaj jakby z ducha czerpią zbudowanie z samego prawa duchowego, które «zawiera cień przyszłych dóbr». Jak zatem mówimy, iż człowiek składa się z ciała, duszy i ducha, tak samo i Pismo święte, którego szczodrobliwość Boża udzieliła dla zbawienia ludzi" (Origenes, De principiis IV 4, 11, SCh 268, 310-312, tł. S. Kalinkowski, Orygenes, O zasadach, PSP 23, Warszawa 1979, s. 301-302).

14 Por. Crouzel, Orygenes, s. 100-103.

15 „Wiara w natchniony charakter Pisma motywuje Orygenesa do podjęcia próby wykazania, że nawet treści ewidentnie irracjonalne i amoralne nie są jawnym bluźnierstwem, lecz muszą wyrażać jakieś prawdy duchowe, zaś ich irracjonalność i amoralność jest de facto tylko pozorna" (M. Domaradzki, Między alegoria a typologia. Uwagi o hermeneutyce Orygenesa, PrzRel 239 (2011) s. 18). Podobne kryteria Orygenesa w stosowaniu duchowej egzegezy przedstawia Emil Stanula. Zob. Stanula, Teologiczne zasady interpretacji Pisma świętego, s. 54-56.

16 Por. J.N.D. Kelly, Początki doktryny chrześcijańskiej, Warszawa 1988, s. 64. 
gólnie widoczna w jego homiliach do ksiąg Starego Testamentu, których sens nie zawsze jest wyraźny i musi być dopiero ujawniony. Według Orygenesa każde zdanie Pisma czy każdy jego większy fragment wskazuje na Chrystusa ${ }^{17}$. W homiliach na Ewangelię według św. Łukasza zaś Orygenes - podobnie jak w komentarzach do Ewangelii według św. Jana i Mateusza - dokonuje chrystologicznej interpretacji w kontekście innych tekstów ewangelicznych, jak i całego Pisma Świętego. Widać wyraźnie, że Orygenes interpretuje Pismo Święte w oparciu o nie samo. Jedność Pisma Świętego jest dla niego zasadniczym kryterium interpretacyjnym $^{18}$. Ten sposób podejścia pozwalał mu dostrzec przeróżne aspekty i treści, które byłyby trudne do odnalezienia, gdy lektura tekstu biblijnego zamknięta była w kontekście jednej tylko księgi ${ }^{19}$.

Dla Orygenesa podmiotem i treścią całego Pisma Świętego jest zatem Jezus Chrystus. Jeśli rozważa on Pismo od strony doktrynalnej, moralnej czy mistycznej, to zawsze jest to dla niego tylko inny sposób patrzenia na jednego i tego samego Chrystusa. To w świetle misterium Chrystusa Orygenes rozumie wszystkie najdrobniejsze szczegóły Pisma, czy to natury literackiej, czy też historycznej. $Z$ jednej strony naświetlają one misterium Chrystusa, a z drugiej w jego świetle nabierają właściwego znaczenia $^{20}$. Nie dziwi więc, że Chrystus jest również główną treścią homilii Orygenesa, które w jego zamierzeniu - podobnie jak cała chrześcijańska

17 Por. Simonetti, Między dosłownościa a alegoria, s. 77-79; Pietras, Wrowadzenie, s. 9.

18 Por. Stanula, Teologiczne zasady interpretacji Pisma świętego, s. 56: „Punkt wyjścia dla Orygenesa stanowi jedność boskiego Objawienia zawartego w Piśmie św. Starego i Nowego Testamentu. Jedność tę widzi na trzech płaszczyznach: twórcy, treści i interpretatora. Twórcą jest Trójca Św.; treścią jest tajemnica Chrystusa; interpretatorem są przede wszystkim ci, którzy mogą uczestniczyć w Duchu Świętym”. Zob. Stanula, Teologiczne zasady interpretacji Pisma świętego, s. 34-48.

19 Por. Pietras, Wprowadzenie, s. 12.

20 Por. Stanula, Teologiczne zasady interpretacji Pisma świętego, s. 43-44. Zob. M. Szram, Chrystus - Mądrość Boża jako klucz interpretacyjny Pisma Świętego w ujęciu Orygenesa, w: Mistrz i przyjaciel. Księga pamiątkowa ku czci Księdza Profesora Marka Tomasza Zahajkiewicza, red. J. Pałucki, Lublin 1997, s. 225-238. 
nauka - winny być wierne słowu Bożemu. Pojmowanie tekstu biblijnego jako wcielenia Logosu oraz chrystologiczna koncentracja przepowiadania Orygenesa sprawia, że jego homilie definiuje się jako poszukiwanie Chrystusa w Piśmie Świętym w obecności słuchaczy. Tym samym jego homilie postrzegane są jako wydarzenie zbawcze urzeczywistniające się w spotkaniu uczestników liturgii z Chrystusem obecnym w Piśmie. Odniesienie misterium Chrystusa do duchowego życia słuchaczy sprawia, że homilia Orygenesa zmierza nie tylko do pouczania, lecz przede wszystkim do nawrócenia serca oraz poznania i umiłowania Boga ${ }^{21}$.

Ów chrystologiczny rys Orygenesowego przepowiadania jest najbardziej aktualną inspiracją dla współczesnej homilii. W obecnej nauce Kościoła odnośnie do homilii na pierwszy plan wybija się jej sakramentalny charakter oraz jej integralny związek z liturgią. Słowem kluczem zaś, rzeczywistością węzłową każdej homilii jest misterium Chrystusa, które ,zawsze jest w nas obecne i działa, zwłaszcza w obrzędach liturgicznych" (KL 35, 2). Nawet jeśli homilia jest wyjaśnianiem tekstu świętego czy przekazem doktryny i zasad moralności, to zawsze winna to czynić w świetle misterium Chrystusa (por. KL 52). Podstawowym celem dzisiejszej homilii jest służba misterium Chrystusa tak, aby mogło ono oddziaływać na wiernych z całą zbawczą mocą 22. Misterium Chrystusa obchodzone w danej celebracji jest nadrzędnym kryterium porządkującym całą celebrację liturgiczną i chrześcijańskie życie ${ }^{23}$. Tematem współ-

21 Por. Olivar, La predicación cristiana antigua, s. 62-69; E. Staniek, Kazanie w starożytności chrześcijańskiej, w: Fenomen kazania, red. W. Przyczyna, Kraków 1994, s. 19.

22 Zob. S. Dyk, Homilia - droga do żywego poznania misterium Chrystusa, Kielce 2016.

23 To misterium Chrystusa decydowało o wyborze takich, a nie innych czytań Lekcjonarza mszalnego czy też tekstów euchologijnych (modlitw zawartych w Mszale). Ono też jest podstawą dla ukazania życiowych postaw, jakich obchodzone misterium domaga się od uczestników celebracji liturgicznej. Ono również staje się natchnieniem dla dziękczynienia stanowiącego pierwszą część modlitwy eucharystycznej. Taki też aspekt zbawczej łaski Chrystusowego misterium wierni przyswajają sobie w Komunii Świętej. Port. S. Czerwik, Homilia o misterium (misteriach) Chrystusa w cyklu roku liturgicznego, PHom 8 (2004) s. 55. 
czesnej homilii powinna być zatem nie tyle jakaś prawda tekstu świętego, lecz sam Chrystus oraz jego żywa i dynamiczna obecność w liturgii i życiu wiernych ${ }^{24}$. Kościół w ciągu roku liturgicznego nie celebruje bowiem jakiejś idei, doktryny, lecz osobę Jezusa Chrystusa. W takim świetle jasne staje się, że podstawowym celem homilii nie jest przekaz chrześcijańskiej doktryny, lecz karmienie wiary. Homilia służy nie temu, by „czegoś nauczyć", lecz temu, by stworzyć warunki do nawiązania osobowego i zbawczego „kontaktu z Kimś”25. Właśnie tego rodzaju intuicja była bardzo bliska Orygenesowi. Jego zdaniem to sam Chrystus jest głównym autorem Objawienia, a tym samym podmiotem przepowiadania. Kaznodzieja jest jedynie Jego narzędziem ${ }^{26}$.

Jednocześnie należy podkreślić, że ów chrystologiczny rys nie prowadzi Orygenesa do zapominania o swoich słuchaczach. Orygenes szuka Chrystusa po to, by duchowo zbudować słuchaczy. Wskazuje na głębię Boga i Jego miłości do swych stworzeń, przestrzega przed niebezpieczeństwem grzechu, podejmuje ważne tematy moralne, jak: bogactwo i ubóstwo, pycha i pokora, praktyki ascetyczne, pokuta, itp. Choć dodać należy w tym miejscu, że w odniesieniu do życia słuchaczy Orygenes koncentruje się głównie na ich duchowym postępie. Bardzo rzadko zaś odnosi się do problemów życia codziennego swoich słuchaczy. Takie podejście Orygenesa wypływa w pewnej mierze z właściwej mu perspektywy teologicznej, w której życie codzienne i moralne wiernych schodziło na dalszy plan - było mądrością ludzi prostych pozostających na początkowym etapie duchowej drogi do Boga. Stąd też, także i po otrzymaniu święceń kapłańskich, a tym samym podjęciu posługi kaznodziejskiej, Orygenes pozostał bardziej uczonym, teologiem i mistrzem niż duszpasterzem skupiającym się na egzystencjalnych problemach słuchaczy ${ }^{27}$. Takie podejście Orygenesa do egzystencji

\footnotetext{
24 Por. M. Augé, Omelie a tema?, „Rivista Liturgica” 95/6 (2008) s. 1065.

25 Por. Augé, Omelie a tema?, s. 1067.

26 Por. Monaci Castagno, Origene, s. 1052.

27 Por. Monaci Castagno, Origene, s. 1053.
} 
swoich słuchaczy nie wytrzymuje krytyki z perspektywy współczesnej homiletyki, a tym samym w tym wymiarze osłabia aktualność jego homilii. Współczesna homilia bowiem winna wyjaśniać tekst święty nie tylko z perspektywy „obchodzonego misterium” (co akurat jest bliskie Orygenesowi), lecz także z uwzględnieniem ,szczególnych potrzeb słuchaczy" (KL 52). Przepowiadanie winno rozjaśniać ludzką egzystencję, odpowiadać na najbardziej intrygujące pytania, interpretować życie słuchaczy w świetle misterium Chrystusa, który zrekapitulował w sobie losy całej ludzkości. Dlatego papież Franciszek nakazuje homilistom, aby w procesie przygotowania homilii potrafili „kontemplować lud”28. W dzisiejszej homiletyce - podobnie jak i w całej teologii - to właśnie połączenie soteriologii i antropologii wskazuje się jako jeden z ważniejszych sposobów odnowienia chrześcijańskiego życia.

Homilie Orygenesa pozostają aktualne, jeśli chodzi o chrystologiczną interpretację tekstów świętych. Jak to już zostało wspomniane, misterium Chrystusa jest dla niego kluczem w zrozumieniu relacji pomiędzy Starym i Nowym Testamentem. Oba przekazują tę samą historię zbawienia, a Stary Testament pojmowany jest jako prefiguracja Chrystusa. Tego rodzaju interpretacja jest właściwa zarówno dla hermeneutyki biblijnej, jak też i dla zrozumienia tekstów świętych w liturgii, której homilia jest częścią. Liturgia odczytuje Pismo Święte w świetle najwyższej zasady jedności misterium Chrystusowego, a zatem jedności dwóch Testamentów i całej świętej historii, jedności organiczno-postępującej pod prymatem Nowego Testamentu nad Starym oraz rzeczywistości eschatologicznych nad rzeczywistością aktualnej ekonomii zbawienia:

28 Franciszek, Adhortacja apostolska o głoszeniu Ewangelii we współczesnym świecie „Evangelii gaudium”, Kraków 2013, nr 154. Autorzy Dyrektorium zaś precyzują to zadanie w sposób następujący: ,Zainteresowanie się tym, co dzieje się w parafii i szerszej społeczności, wraz z namysłem i modlitwą, wskaże kierunki refleksji nad przesłaniem słowa Bożego dla danej wspólnoty w danym czasie. Nieustanne rozeznawanie wzorca śmierci i zmartwychwstania Chrystusa w życiu wspólnoty i świata będzie owocem takich rozmyślań i wpłynie istotnie na treści homilii” (Dyrektorium Homiletyczne 33). 
Kiedy Kościół w sprawowaniu liturgii czyta zarówno Stary, jak i Nowy Testament, zwiastuje jedno i to samo misterium Chrystusa. W Starym Testamencie kryje się bowiem Nowy, a Nowy Testament odsłania się w Starym. Chrystus jest ośrodkiem i pełnią zarówno całego Pisma św., jak i całej liturgii, trzeba więc, aby z Jego źródeł czerpali wszyscy, którzy szukają zbawienia i życia ${ }^{29}$.

Dlatego też w liturgii Pismo Święte interpretuje się zawsze w duchu chrystologicznym. Zwraca się przy tym uwagę na wspomnianą już „treść i jedność całego Pisma św." (KKK 112), z czym wiąże się perspektywa zapowiedzi i wypełnienia, interpretacja typologiczna i kontekst historii zbawienia (por. KO 15). Celebrowanie Chrystusa jest więc celebracją Pisma i odwrotnie. Współczesny homilista może także odnaleźć w homiliach Orygenesa interpretacje właściwe dla obecnie rozumianej typologii ${ }^{30}$, która jest jednym z kryteriów zrozumienia obecnego lekcjonarza.

Cenną i aktualną inspiracją dla współczesnego przepowiadania jest intuicja Orygenesa dotycząca otwarcia się na działanie Ducha Świętego pojmowanego jako twórcę i głównego egzegetę Pisma. Według Orygenesa odkrycie duchowego sensu Pisma Świętego, a tym samym dotarcie do Chrystusa - do boskiej mądrości ukrytej w tekście świętym jest możliwe tylko dzięki natchnieniu Ducha ${ }^{31}$. Stąd też Orygenes nie waha się modlić w czasie swych homilii, zwłaszcza wtedy gdy znajduje się wobec

29 Święta Kongregacja Kultu Bożego, Wprowadzenie do drugiego wydania Lekcjonarza mszalnego, Poznań 2011, nr 5.

30 Por. K. Bardski, Patrystyczna egzegeza alegoryczna, VoxP 44-45 (2003) s. 62-63; Domaradzki, Między alegoria a typologia, s. 22-23; Stanula, Teologiczne zasady interpretacji Pisma świętego, s. 52. Zob. np. A. Tronina, Jozue - Jezus. Biblijna typologia Zbawiciela, VV 1 (2002) s. 53-54. Typologię definiuje się dziś jako analogiczny sposób myślenia i mówienia, który skupia uwagę na dwóch albo więcej rzeczywistościach (np. Adamie i Chrystusie) i ujmuje w ten sposób istniejący między nimi związek. Kryterium typologii uwydatnia zatem ścisły związek obu Testamentów i polega na dostrzeganiu w osobach, wydarzeniach, czynnościach, prawach, budynkach, instytucjach Starego Testamentu ich zapowiedzi i znaki dla przyszłości.

31 Por. Stanula, Teologiczne zasady interpretacji Pisma świętego, s. 52. 
trudniejszych partii tekstu świętego ${ }^{32}$. Również i we współczesnej homiletyce kładzie się nacisk na konieczność duchowego odczytania tekstu Pisma przez kaznodzieję. W Piśmie Świętym bowiem Bóg mówi do człowieka w sposób ludzki, dlatego też oprócz sensu zamierzonego przez autora tekstu biblijnego (sensu dosłownego) homilista powinien poszukiwać w nim sensu zamierzonego przez Boga, sensu zawsze aktualnego - skierowanego do ludzi wszystkich czasów (por. KKK 111; KO 12, 25). Pismo Święte winno być interpretowane w tym samym Duchu, w jakim zostało spisane (por. KO 12). Duch Święty nie przybliża nas bowiem do jakichś abstrakcyjnych prawd teologicznych, lecz do żywej osoby Jezusa Chrystusa. Chrystus zmartwychwstały bowiem wskrzeszony mocą Ducha „,̇yje w Duchu” i udziela się w Duchu, dlatego poza Duchem można odnaleźć jedynie Chrystusa „martwego" 33 . Warto dodać w tym względzie uwage papieża Benedykta XVI, który mówił o współczesnym problemie hermeneutyki zlaicyzowanej - egzegezy Pisma oderwanej od wiary Kościoła, od modlitwy i Ducha Świętego; egzegezy, która czyni z Biblii jedynie dokument historyczny i ludzki ${ }^{34}$. Nic dziwnego zatem, że autorzy Dyrektorium Homiletycznego zachęcają: ,chociaż metody egzegetyczne mogą się przydać do przygotowania homilii, to jednak homilista musi się wykazywać wrażliwością na sens duchowy Pisma św." ${ }^{35}$.

Duchowe podejście interpretacyjne Orygenesa otwierało drogę do wielorakiej, ciągle nowej interpretacji danego tekstu biblijnego - sens duchowy, jako ukryty w możności Bożej, pozostaje zawsze tajemnicą

32 Por. Monaci Castagno, Origene, s. 1052; Crouzel, Orygenes, s. 93.

33 Por. R. Cantalamessa, Twoje słowo daje mi życie, Wrocław 2009, s. 82-96.

34 Benedykt XVI, Adhortacja apostolska o słowie Bożym w życiu i misji Kościoła „, Verbum Domini”, Poznań 2010, nr 35-36.

35 Dyrektorium Homiletyczne 24: „Definicja tego sensu podana przez Papieską Komisję Biblijną wskazuje, że ta metoda interpretacji szczególnie pasuje do liturgii: chodzi o «sens wyrażany przez teksty biblijne, odczytywane pod natchnieniem Ducha Świętego w kontekście tajemnicy paschalnej Chrystusa i nowego życia, któremu ta tajemnica daje początek. Taki kontekst rzeczywiście istnieje. Nowy Testament właśnie w nim widzi wypełnienie się Pisma. Jest więc rzeczą normalną odczytywać Pismo Święte w świetle tego nowego kontekstu, którym jest życie w Duchu Świętym»”. 
i jest niezmierzony ${ }^{36}$. Do odkrycia ukrytego sensu duchowego, zgłębiania „spraw Bożych” (por. 1Kor 2,13) służyła Orygenesowi alegoria, którą stosował bardzo często. Alegoryzował etymologię imion i nazw hebrajskich, zwierząt, roślin, przedmiotów, zwyczajów, miejsc, liczb ${ }^{37}$. W tych wszystkich rzeczywistościach poszukiwał symboli życia duchowego: postępu w oderwaniu się od rzeczywistości zmysłowych, walki przeciwko grzechowi i szatanowi, zdobywania cnót, duchowego wzrostu ${ }^{38}$.

Warto w tym miejscu wspomnieć, że alegoria jako taka często niesie ze sobą ryzyko interpretacji dowolnej, niekoniecznie zgodnej z intencją autora biblijnego ${ }^{39}$. Opiera się bowiem na założeniu, że pod sensem literalnym tekstu kryje się inne, głębsze ukryte znaczenie duchowe. Pomimo, że - jak stwierdza Henryk Pietras - homilie Orygenesa, w porównaniu do jego komentarzy, cechowały się mniej rozbudowaną alegorią $^{40}$, to u współczesnego homilisty mogą pojawić się znaki zapytania związane z wykorzystaniem przepowiadania Orygenesa na ambonie. $\mathrm{Z}$ jednej strony jego duchowa egzegeza nie zawsze wytrzymuje krytykę współczesnej egzegezy biblijnej ${ }^{41}$. Z drugiej strony należy jednak pamiętać, aby - jak to podkreśla Mikołaj Domaradzki - alegorię Orygenesa nie oceniać z perspektywy osiągnięć nowożytnej hermeneutyki biblijnej, lecz raczej w kontekście jego próby przezwyciężenia współczesnego mu

36 Por. Pietras, Wprowadzenie, w: Homilie o Księdze Rodzaju. Homilie o Księdze Wyjścia, s. 9; H. Pietras, Początki teologii Kościoła, Kraków 2000, s. 134.

37 Por. Składanowski, Myśl Orygenesa. Metodologiczne intuicje dla współczesnych teologów, s. 160; Kelly, Początki doktryny chrześcijańskiej, s. 62.

38 Por. Monaci Castagno, Origene, s.1053.

39 Należy w tym miejscu dodać, że Orygenes, ,żadnej swojej interpretacji nie traktował jako najlepszej i ostatecznej. Szukał w Piśmie tego, co duchowe i pożyteczne dla wiary, zdawał sobie sprawę, że słowo Boże jest żywe i do każdego przemawia inaczej, każdy więc coś innego może w nim odnaleźć; nie na zasadzie dowolności interpretacji, ale z racji różnego poziomu rozumienia, różnej zażyłości z Bogiem i nieskończonej głębi tekstu" (Pietras, Wprowadzenie, s. 10).

40 Por. Pietras, Wprowadzenie, s. 12.

41 Por. R. Hanson, Allegory and Event: A Study of the Sources and Significance of Origen's Interpretation of Scripture, Louisville 2002, s. 209; F. Young, Biblical Exegesis and the Formation of Christian Culture, Cambridge 1997, s. 15. 
naiwnego antropomorfizmu i społecznie szkodliwego literalizmu w podejściu do tekstu świętego. Wówczas okazuje się, że egzegeza Orygenesa jest bardzo antyfundamentalistyczna, stając tym samym w obronie Pisma jako tekstu natchnionego przez Boga, ukazującego Jego zbawcze działanie oraz mającego uniwersalne, moralne i chrystologiczne znaczenie. Alegoria Orygenesa nie unieważnia też sensu dosłownego i nie niweluje historycznej wartości Pisma ${ }^{42}$. Jego duchowa egzegeza broni się także poprzez stosowanie interpretacji Pisma przez samo Pismo, co jest dziś ogólnie przyjętą zasadą hermeneutyki biblijnej.

Współczesny homilista powinien mieć świadomość tego zróżnicowanego podejścia do dzieł Orygenesa. Zanim zatem w dosłowny sposób przeniesie on myśl Orygenesa do swojej homilii, warto, aby zestawił ją z wynikami współczesnej egzegezy biblijnej. W ten sposób zbliży się do pełniejszego sensu tekstu świętego. Poprawna interpretacja Biblii, a zarazem aktualizacja jej orędzia, wymaga także od homilisty stosowania teologicznych zasad interpretacji, do których należą powaga interpretacyjna Tradycji, analogia wiary (porównanie wyników egzegezy z ustalonymi prawdami wiary), jedność całej Biblii, interpretowanie tekstów w kontekście historii zbawienia (por. KO 10-16; KKK 109-114) ${ }^{43}$. Te zasady interpretacyjne były bliskie Orygenesowi. Wspominaliśmy już, że nietrudno zauważyć w jego interpretacji akcent położony na jedności całej Biblii. Niejednokrotnie kierował on także wzrok odbiorcy swych homilii nie tyle na własne interpretacje, co na powagę Kościoła, kładąc nacisk na obecną w nim ciągłość przekazu wiary, począwszy od Chrystusa i Apostołów ${ }^{44}$. Warto zaznaczyć, że gdy Dyrektorium Homiletyczne przypomina, aby czytać Pismo Święte w nurcie żywej tradycji Kościoła, przytacza właśnie jego wypowiedź:

42 Zob. Domaradzki, Między alegoria a typologia, s. 17-27; Crozuel, Orygenes, s. 100-120; H. de Lubac, Pismo Święte w tradycji Kościoła, Kraków, 2008, s. 26-58.

43 Por. Dyrektorium Homiletyczne 17-21; Benedykt XVI, Verbum Domini 29-30, 34 , 39; Papieska Komisja Biblijna, Interpretacja Biblii w Kościele, s. 90 (IV C, 3).

44 Por. Bardski, Patrystyczna egzegeza alegoryczna, s. 56. 
Według powiedzenia ojców Kościoła [...] „Pismo Święte jest bardziej wypisane na sercu Kościoła niż na pergaminie”. Istotnie, Kościół nosi w swojej tradycji żywą pamięć słowa Bożego, a Duch Święty przekazuje mu duchową interpretację Pisma Świętego [...] „według sensu duchowego, który Duch daje Kościołowi” (Orygenes, Homiliae in Leviticum 5, 5) (KKK 113)

Ta myśl winna nieco „uspokajać” zbyt pochopnych krytyków Orygenesowej egzegezy Pisma i jednocześnie ośmielać współczesnych homilistów w sięganiu po jego homilie, aby uczyć się od ich autora twórczego, żywego i otwartego na dobro duchowe słuchaczy kontaktu z tekstem świętym ${ }^{46}$.

W tym miejscu warto dodać, że alegoria jako osobista metoda interpretacji Pisma będzie zawsze pozostawiać pytania, nastręczać konkretnych trudności, a czasem prowadzić do niepewnych interpretacji. Uwaga ta jest bardzo aktualna. Uważna obserwacja świata mediów elektronicznych pokazuje, że alegoryczna interpretacja tekstu biblijnego wykorzystywana jest dziś często przez bardzo popularnych kaznodziejów. Z symbolicznego znaczenia imienia bohatera opowiadania biblijnego czy też z alegorycznej interpretacji jakiegoś innego szczegółu perykopy wyciągają oni wnioski kerygmatyczne, które zaważają na wymowie całego kazania. Warto zatem przypomnieć, że sens alegoryczny, zwany też

45 Dyrektorium Homiletyczne 17, 2.

46 Warto w tym miejscu przytoczyć zachętę, jaką autorzy Dyrektorium Homiletycznego stosują do współczesnym homilistów: „Znajomość piśmiennictwa patrystycznego może się okazać dla homilisty wielką pomocą w odkrywaniu duchowego sensu Pisma Świętego. Właśnie dzięki przepowiadaniu ojców Kościoła poznajemy, jak głęboka więź łączy Stary i Nowy Testament. możemy się od nich nauczyć odkrywania nieprzeliczonych figur i wzorców tajemnicy paschalnej, które są obecne w świecie od brzasku stworzenia i dalej odsłaniają się poprzez dzieje Izraela odnajdujące szczyt w Jezusie Chrystusie. Właśnie od ojców Kościoła dowiadujemy się, że nieomal każde słowo pism natchnionych może przynosić niespodziewane i nieprzebrane bogactwa, jeżeli rozważa się je w sercu życia i modlitwy Kościoła. Właśnie od ojców dowiadujemy się, jak ściśle tajemnica słowa biblijnego wiąże się z tajemnicą celebracji eucharystycznej" (Dyrektorium Homiletyczne 25). 
duchowym, jest sensem odkrytym na modlitwie przy asystencji Ducha Świętego. Nikt nie dysponuje jednak kryterium, które pomogło by mu jasno rozstrzygnąć, czy dana interpretacja dokonana została w Duchu Świętym. Należy także pamiętać o zagrożeniach towarzyszących stosowaniu alegorii w obecnych czasach. Są nimi m.in. deprecjacja wymiaru historycznego i sensu dosłownego Pisma Świętego, traktowanie tekstu biblijnego w sposób magiczny właściwy duchowi gnostyckiemu, niebezpieczeństwo subiektywizmu wynikające z niekontrolowanego posługiwania się własną wyobraźnią ${ }^{47}$. Wyniki osobistej interpretacji duchowej należy zatem zawsze skonfrontować - jak to zostało wspomniane już wcześniej - z osiągnięciami egzegezy biblijnej, która pomaga odkryć sens dosłowny Pisma oraz z żywą Tradycją Kościoła zawierającą spuściznę wielowiekowej, duchowej tradycji interpretacyjnej.

\section{Orygenes jako „ojciec” homilii egzegetycznej}

Orygenes stworzył formę homilii zwanej dziś egzegetyczną lub analityczną. Jej kompozycja polega na wyjaśnieniu tekstu biblijnego wiersz po wierszu w sposób dostosowany do mentalności słuchaczy, któremu towarzyszy wyprowadzanie z czytań biblijnych wniosków dotyczących zasad życia moralnego. Orygenes uważał bowiem, że prawda Ewangelii ma być przekazywana także w ewangelicznej formie, czyli tak, jak ją mamy podaną w Piśmie Świętym ${ }^{48}$. Skoro uznaje on Pismo Święte jako nową postać wcielenia Syna Bożego, to forma tekstu biblijnego jest dla niego szatą Syna Bożego, podobnie jak Jego ludzkie ciało i podobnie jak

47 Por. Bardski, Patrystyczna egzegeza alegoryczna, s. 53-55.

48 Por. Monaci Castagno, Origene, s. 1052-1053. Według Edwarda Stańka to właśnie ów ewangeliczny styl, wierność ewangelicznej formie i językowi są zasadniczą cechą, która odróżnia starożytną homilię od kazania. Por. Staniek, Koncepcja homilii patrystycznej, s. 25-26. 
Kościół ${ }^{49}$. W podobny sposób uważają niektórzy współcześni homileci. Twierdzą oni, że forma uczestniczy w jakiś sposób w treści tekstu, stąd też wierność formie danej perykopy biblijnej zabezpiecza przepowiadanie przed wypaczeniem jej kerygmatu ${ }^{50}$. Oczywiście odnosi się to głównie do wewnętrznej dynamiki tekstu, a nie do samego języka Biblii, który zawsze powinien być uwspółcześniony.

Warto wspomnieć, że Orygenesową formę homilii egzegetycznej przejęli następni, wielcy Ojcowie Kościoła, jak św. Ambroży, św. Augustyn, św. Grzegorz Wielki. Od drugiej połowy VI wieku zaś rozwiną się zwyczaj odczytywania ich homilii w liturgii ze zbiorów zwanych homiliarzami. Ta praktyka prawdopodobnie utrwaliła bardziej egzegetyczne rozumienie homilii, które w świadomości wielu kapłanów trwa aż do dziśs ${ }^{51}$. Należy jednak pamiętać, że Sobór Watykański II zmienił koncepcję homilii, nadając jej bardziej mistagogiczny wymiar, wiążąc jej treść z misterium Chrystusa uobecnionym w liturgii ${ }^{52}$.

Jeśli chodzi o kompozycję Orygenesowej homilii, to jest ona dzisiaj raczej niemożliwa do zastosowania w przepowiadaniu liturgicznym.

49 Por. Monaci Castagno, Origene, s. 29.

50 Zob. np. S. Greidanus, The Modern Preacher and the Ancient Text. Interpreting and Preaching Biblical Literature, Leicester 1988, s. 20-23; W. Przyczyna, Kaznodziejski przekaz opowiadań biblijnych, Kraków 2000, s. 7.

51 Homilia egzegetyczna, zwana później analityczną, rozumiana jako omówienie poszczególnych wierszy danej perykopy, w której wyjaśniano każdy wyraz i myśl danego tekstu znana jest aż do XX wieku. Homilię definiowano wówczas jako przemówienie religijne, w którym kaznodzieja wobec słuchaczy dorosłych w sposób prosty i popularny wyjaśnia tekst perykopy biblijnej, wykładając zawarte w niej prawdy wiary i moralności oraz czyniąc praktyczne zastosowanie życiowe. Zasadniczo wyróżniano właśnie dwa rodzaje homilii: analityczną i syntetyczną. Zob. M. Brzozowski, Teoria kaznodziejstwa, w: Dzieje teologii katolickiej w Polsce, t. 3: Wiek XIX i XX, cz. 2, Lublin 1977, s. 107-108.

52 Por. Dyrektorium Homiletyczne 11: „Tym, co odróżnia homilię od innych form nauczania, jest jej kontekst liturgiczny. Ujęcie to staje się węzłowe, kiedy ramą homilii jest celebracja eucharystyczna; to, o czym w tej kwestii mówią dokumenty, jest nieodzowne do właściwego zrozumienia celu homilii. Liturgia słowa i liturgia Eucharystii razem obwieszczają cudowne dzieło Boże naszego zbawienia w Chrystusie. Albowiem paschalne misterium Chrystusa, głoszone w czytaniach i homilii, urzeczywistnia się przez ofiarę Mszy Świętej”. 
Głównym źródłem współczesnej homilii są teksty święte zawarte w lekcjonarzu i mszale. Lekcjonarz zawiera w sobie zestawy tekstów, które winny być odczytywane $\mathrm{w}$ powiązaniu ze sobą. $\mathrm{Z}$ racji ograniczeń czasowych trudno zatem o analizę wszystkich czytań, zdanie po zdaniu na wzór Orygenesowej homilii. Z kolei pozostanie przy wyjaśnieniu tylko jednego z tekstów niwelowałoby nieco hermeneutykę lekcjonarza, która domaga się syntezy czytań mszalnych. Również i papież Franciszek podkreśla wartość homilii, która ,polega na przekazaniu syntezy ewangelicznego orędzia, a nie idei czy wartości niepowiązanych ze sobą"53. Co prawda niektórzy wskazują homilię analityczną za możliwą do zastosowania również i dziś, uznając ją jednocześnie za jedno z najbardziej prostych ujęć aktualizacji biblijnej ${ }^{54}$. Trzeba jednak stwierdzić, że kompozycja homilii Orygenesa nadaje się do wykorzystania raczej w przepowiadaniu pozaliturgicznym, na przykład jako bardziej „biblijna” odmiana kazania katechetycznego. W tym przypadku należy jednak uważać, aby nie utożsamić formy takiego kazania z lekcją egzegezy biblijnej.

Tym, co w formie homilii Orygenesa może posłużyć za przykład także i dziś, jest jej styl. Orygenes, zamiast uciekać się do wyszukanej retoryki, stosuje styl bardzo prosty ${ }^{55}$, ufając bardziej mocy Ducha Świętego niż sztuce wymowy. $Z$ tego też powodu sprawy związane z procesem komunikacji pozostawały u niego na drugim planie. Homilie Orygenesa nie są oczywiście całkowicie pozbawione elementów retorycznych - w jego przepowiadaniu łatwo dostrzec choćby elementy ówczesnej diatryby. Akcent położony jest tu jednak na doświadczeniu Orygenesa mistrza niż na jego sztuce oratorskiej. Szuka on przede wszystkim bezpośredniej relacji ze swoimi słuchaczami, stawia im pytania, napomina, pobudza do uważnego słuchania. Wykorzystując zaimki „ty” lub „my”, zmierza do tego, aby słuchacze osobiście zaangażowali się w słuchanie i poczuli się

\footnotetext{
53 Franciszek, Evangelii gaudium 143.

54 Por. Twardy, Aktualizacja słowa Bożego w kaznodziejstwie, s. 142.

55 Por. Crouzel, Orygenes, s. 94-95.
} 
bohaterami przedstawianych wydarzeń zbawczych ${ }^{56}$. Homilie Orygenesa są zatem bezpośrednią i swobodną formą wypowiedzi, popularnym wyjaśnieniem i duchową aplikacją tekstu biblijnego. Styl Orygenesa jest bliski współczesnej homilii, której język winien charakteryzować się prostotą, jasnością, przejrzystością ${ }^{57}$, bezpośredniością, a przede wszystkim dialogicznością. Dzisiejsza homilia winna być utrzymana w stylu rodzinnej, przyjacielskiej rozmowy, o której Franciszek powie, że ma przypominać rozmowę matki z dziećmi oraz rozpalać serca w oczekiwaniu na spotkanie $z$ Panem $^{58}$. Tak rozumiana homilia wolna jest od patosu i nadmiernego przeładowania elementami retorycznymi, co nie znaczy oczywiście, że nie powinna kierować się prawami rządzącymi komunikacją ${ }^{59}$.

\section{Podsumowanie}

Przeprowadzone analizy wykazały, że homilie Orygenesa pozostają aktualne pod wieloma względami. Przede wszystkim należy podkreślić chrystologiczną koncentrację jego przepowiadania. Takie same podejście reprezentują dokumenty Kościoła odnośnie do współczesnej homilii, zarówno wtedy gdy misterium Chrystusa wskazują jako centralną treść homilii (por. KL 35, 2), jak też i wówczas, gdy misterium to przedstawiane jest jako główne kryterium interpretacji tekstów świętych. Homiletyczna metoda Orygenesa polegała na poszukiwaniu Chrystusa w tekście świę-

56 Por. Monaci Castagno, Origene, s. 1052.

57 Por. M. Klementowicz, Spójność tekstu jako warunek poprawnej homilii, RT 64/12 (2017) s. 64.

58 Por. Franciszek, Evangelii gaudium 139-144.

59 Należy podkreślić, że w obecnej dobie kapłani winni starać się dorównywać retorycznej i komunikacyjnej sztuce profesjonalistów radia i telewizji oraz dokładać starań, aby orędzie ich homilii rozbrzmiewało w sposób zdecydowanie atrakcyjny i jasny, w czym pomaga wykorzystanie osiągnięć współczesnej retoryki. Por. Kongregacja ds. Duchowieństwa. Kapłan głosiciel Słowa, szafarz sakramentów i przewodnik wspólnoty $w$ drodze do trzeciego tysiaclecia chrześcijaństwa, Tarnów 1999, s. 32, 35. 
tym w obecności słuchaczy, czyli na proklamacji Jego misterium w odniesieniu do duchowego życia słuchaczy. Pytanie o duchowy pożytek słuchacza stało u podstaw jego przepowiadania. Takiemu podejściu Orygenesa nie towarzyszyła jednak głęboka wrażliwość na egzystencjalne problemy słuchaczy, co z dzisiejszej perspektywy osłabia aktualność jego homilii. Aktualna pozostaje zaś Orygenesowa świadomość ludzkich ograniczeń w zrozumieniu tekstu biblijnego, a tym samym otwartość na natchnienie Ducha Świętego, głównego „egzegety” Pisma. Wartościową dla współczesnego homilisty jest także Orygenesowa, duchowa interpretacja Pisma, zwłaszcza jeśli chodzi o egzegetyczną pokorę, poszukiwanie sensu w świetle jedności całej Biblii i przez pryzmat misterium Chrystusa. Homilista może czerpać także z przykładów Orygenesowej typologii, która bliska jest jej obecnemu ujęciu. Pod względem formalnym homilie Orygenesa pozostają mniej aktualne, jeśli chodzi o kompozycję polegającą na wyjaśnieniu tekstu świętego wiersz po wierszu. Taki sposób przepowiadania trudno zaaplikować do dzisiejszej homilii liturgicznej. Aktualny pozostaje zaś styl homilii Orygenesa, zwłaszcza jeśli chodzi o prostotę języka, bezpośredniość, dialogiczność i troskę o zaangażowanie słuchacza. Należy przy tym pamiętać, że z racji ograniczeń czasowych i kulturowych nie wszystkie sformułowania Orygenesa nadają się do dosłownego przeniesienia na współczesną ambonę.

\section{The Actuality of Origen's Homilies in Modern Preaching}

(summary)

The goal of the article was to show the extent to which Origen's homilies can be used as an example and inspiration for contemporary homily. It focused on the formal aspects of Origen's preaching. Origen was seen as a master for spiritual interpretation of the Holy Scriptures and a "father" of the exegetical homily. His method of working with the sacred text and communicating its saving message were compared with the instructions for homilies contained in contemporary Church documents and theological reflections. The analyzes carried out led to the following conclusions: Origen's homilies are still current in terms of the Christological focus of their contents; the spiritual interpretation of the Bible is combined with openness to the light of the Holy Spirit; and his direct, simple and 
dialogical style of preaching. On the other hand, objections are raised due to the lack of reference to the everyday life problems of his listeners; Origin's homilies are not acceptable today regarding their composition, since he explains the sacred text verse by verse.

Keywords: Origen; mystery of Christ; spiritual interpretation; allegory; exegetical homily

\section{Aktualność homilii Orygenesa we współczesnym przepowiadaniu}

(streszczenie)

Celem artykułu było wykazanie, na ile homilie Orygenesa mogą być inspiracją dla współczesnego przepowiadania homilijnego. Skupiono się przy tym na formalnych aspektach przepowiadania Orygenesa. Wskazano na Orygenesa jako na mistrza duchowej interpretacji Pisma Świętego oraz „ojca” homilii egzegetycznej. Jego metodę pracy nad tekstem świętym oraz sposób komunikacji zbawczego orędzia porównano ze wskazaniami dotyczącymi homilii zawartymi we współczesnych dokumentach Kościoła i refleksji teologicznej. Przeprowadzone analizy doprowadziły do następujących wniosków: homilie Orygenesa są aktualne pod względem chrystologicznej koncentracji swej treści, duchowej interpretacji Pisma Świętego połączonej z otwartością na światło Ducha Świętego oraz bezpośredniego, prostego i dialogicznego stylu przepowiadania. Zastrzeżenie budzi natomiast zbyt małe odniesienie do problemów życia codziennego swych słuchaczy. Nie do utrzymania jest także kompozycja Orygenesowej homilii polegająca na wyjaśnieniu tekstu świętego wiersz po wierszu.

Słowa kluczowe: Orygenes; misterium Chrystusa; interpretacja duchowa; alegoria; homilia egzegetyczna

\section{Bibliografia \\ Źródła}

Origenes, De principiis, ed. H. Crouzel - M. Simonetti, SCh 252, Paris 978; SCh 253, Paris 1978; SCh 268, Paris 1980; SCh 269, Paris 1980, tł. S. Kalinkowski, Orygenes, $O$ zasadach, PSP 23, Warszawa 1979.

Origenes, In Genesim hom., ed. H. de Lubac - L. Doutreleau, SCh 7bis, Paris 1985, tł. S. Kalinkowski, Orygenes, Homilie o Księdze Rodzaju, w: Orygenes, Homilie o Księdze Rodzaju. Homilie o Księdze Wyjścia, ŹMT 64, Kraków 2012, s. 21-165.

\section{Opracowania}

Augé M., Omelie a tema?, „Rivista Liturgica” 95/6 (2008) s. 1060-1067.

Bardski K., Patrystyczna egzegeza alegoryczna, „Vox Patrum” 44-45 (2003) s. 49-64. 
Benedykt XVI, Adhortacja apostolska o słowie Bożym w życiu i misji Kościoła „, Verbum Domini”, Poznań 2010.

Brzozowski M., Teoria kaznodziejstwa, w: Dzieje teologii katolickiej w Polsce, t. 3: Wiek XIX $i$ XX, cz. 2, Lublin 1977, s. 75-121.

Cantalamessa R., Twoje słowo daje mi życie, Wrocław 2009.

Crouzel H., Orygenes, Kraków 2004.

Czerwik S., Homilia o misterium (misteriach) Chrystusa w cyklu roku liturgicznego, PHom 8 (2004) s. 45-57.

De Lubac H., Pismo Święte w tradycji Kościoła, Kraków 2008.

Domaradzki M., Między alegoria a typologia. Uwagi o hermeneutyce Orygenesa, PrzRel 239 (2011) s. 17-27.

Dyk S., Homilia - droga do żywego poznania misterium Chrystusa, Kielce 2016.

Franciszek, Adhortacja apostolska o głoszeniu Ewangelii we współczesnym świecie „Evangelii gaudium”, Kraków 2013.

Greidanus S., The Modern Preacher and the Ancient Text. Interpreting and Preaching Biblical Literature, Leicester 1988.

Hanson R., Allegory and Event: A Study of the Sources and Significance of Origen's Interpretation of Scripture, Louisville 2002.

Kelly J.N.D., Początki doktryny chrześcijańskiej, tł. J. Mrukówna, Warszawa 1988.

Klementowicz M., Spójność tekstu jako warunek poprawnej homilii, RT 64/12 (2017) s. $63-77$.

Kongregacja ds. Duchowieństwa, Kapłan głosiciel Słowa, szafarz sakramentów i przewodnik wspólnoty w drodze do trzeciego tysiąclecia chrześcijaństwa, Tarnów 1999.

Kongregacja Kultu Bożego i Dyscypliny Sakramentów, Dyrektorium Homiletyczne, Poznań 2015.

Monaci Castagno A., Origene predicatore ed il suo pubblico, Milano 1987.

Monaci Castagno A., Origene, w: Dizionario di Omiletica, red. M. Sodi - A.M. Triacca, Torino - Bergamo 1998, s. 1050-1053.

Olivar A., La predicación cristiana antigua, Barcelona 1991. 
Panuś K., Przesłanie Ojców Kościoła dla współczesnego kaznodziejstwa, RBL 1 (2008) s. 127-135.

Papieska Komisja Biblijna, Interpretacja Biblii w Kościele, w: Interpretacja Biblii w Kościele. Dokument Papieskiej Komisji Biblijnej z komentarzem biblistów polskich, red. R. Rubinkiewicz, Warszawa 1999, s. 24-100.

Pietras H., Początki teologii Kościoła, Kraków 2000.

Pietras H., Wprowadzenie, w: Orygenes, Komentarz do Ewangelii wedtug św. Jana, tł. S. Kalinkowski, ŹMT 27, Kraków 2005, s. 5-15.

Pietras H., Wprowadzenie, w: Orygenes, Homilie o Księdze Rodzaju. Homilie o Księdze Wyjścia, tł. S. Kalinkowski, ŹMT 64, Kraków 2012, s. 5-18.

Przyczyna W., Kaznodziejski przekaz opowiadań biblijnych, Kraków 2000.

Simonetti M., Między dosłownościa a alegorią. Przyczynek do historii egzegezy patrystycznej, tł. T. Skibiński, Kraków 2000.

Składanowski M., Myśl Orygenesa. Metodologiczne intuicje dla współczesnych teologów, „Studia Ełckie” 14 (2013) s. 151-164.

Staniek E., Kazanie w starożytności chrześcijańskiej, w: Fenomen kazania, red. W. Przyczyna, Kraków 1994, s. 15-27.

Staniek E., Koncepcja homilii patrystycznej, „Vox Patrum” 44-45 (2003) s. 23-34.

Stanula A., Teologiczne zasady interpretacji Pisma świętego, w: Orygenes, O zasadach, tł. S. Kalinkowski, PSP 23, Warszawa 1979, s. 34-56.

Stanula E., Homiletyczna działalność Orygenesa, w: Orygenes, Homilie o Księdze Jeremiasza, Homilie o Księgach Samuela i Księgach Królewskich, tł. S. Kalinkowski, PSP 30, Warszawa 1983, s. 5-20.

Święta Kongregacja Kultu Bożego, Wprowadzenie do drugiego wydania Lekcjonarza mszalnego, Poznań 2011.

Szewczyk L., Ojcowie bardzo zalecani. Znaczenie kaznodziejstwa Ojców Kościoła dla współczesnego przepowiadania słowa Bożego, w: Omnia tempus habent. Miscellanea theologica Vincentio Myszor quadragesimum annum laboris scientifici celebranti ab amicis, sodalibus discipulisque oblata, red. A. Reginek - G. Strzelczyk - A. Żądło, Katowice 2009, s. 283-291. 
Szram M., Chrystus - Mądrość Boża jako klucz interpretacyjny Pisma Świętego w ujęciu Orygenesa, w: Mistrz i przyjaciel. Księga pamiątkowa ku czci Księdza Profesora Marka Tomasza Zahajkiewicza, red. J. Palucki, Lublin 1997, s. 225-238.

Szram M., Homilia i kazanie patrystyczne jako wzorzec dla współczesnych kaznodziejów, w: Integralne kształcenie kaznodziei, red. W. Broński, Lublin 2006, s. 159-171.

Tronina A., Jozue - Jezus. Biblijna typologia Zbawiciela, VV 1 (2002) s. 41-56.

Twardy J., Aktualizacja słowa Bożego w kaznodziejstwie, Przemyśl 2009.

Young F., Biblical Exegesis and the Formation of Christian Culture, Cambridge 1997. 